\title{
除草剤セトキシジムおよび代謝物の作物残留分析
}

\author{
五 明 健，川上 肇，時枝正則 \\ 杉岡克己，小林 茂，小野成男 \\ 日本曹達株式会社安全性研究所 \\ (昭和 62 年 5 月 22 日受理)
}

\section{Residue Analysis of Herbicide Sethoxydim and Its Metabolites in Crops}

\author{
Takeshi Gomyo, Hajime Kawakami, Masanori Tokieda, \\ Katsumi Sugioka, Shigeru Kobayashi and Shigeo Ono \\ Environmental Toxicology Laboratory, Nippon Soda Co., Ltd., \\ Takada, Odawara 250-02, Japan
}

\begin{abstract}
Two analytical methods for residues of sethoxydim [( \pm )2-(1-ethoxyiminobutyl)-5-[2(ethylthio)propyl]-3-hydroxycyclohex-2-enone, STM] and its metabolites in crops, one using HPLC and the other using GC, were investigated. The results by the two method suggested that the HPLC method is more suitable. STM and its metabolites were extracted with methanol. After they were converted into three compounds $\mathrm{M}_{2}-\mathrm{SO}_{2}, \mathrm{M} 1-\mathrm{SO}_{2}$ and $6-\mathrm{OH}-\mathrm{M} 2-\mathrm{SO}_{2}$, the derivatives cleaned up by column chromatography, followed by HPLC determination. The detection limit for STM and its metabolites was $0.05 \mathrm{ppm}$. The recovery of STM and its metabolites ranged from 70 to $96 \%$. The analyses of crops treated with STM showed that a majority of residue was metabolites unified to $\mathrm{M}_{2}-\mathrm{SO}_{2}$ (mainly $\mathrm{M}-\mathrm{SO}$ and $\mathrm{M}-\mathrm{SO}_{2}$ ). Hydroxylated metabolites (mainly 5-OH-M-SO ${ }_{2}$ ) unified to 6-OH- 2 2- $\mathrm{SO}_{2}$ were detected in a few crops. The residual amount of the metabolites unified to $\mathrm{M} 1-\mathrm{SO}_{2}$ was negligibly small in all crops.
\end{abstract}

\section{緒言}

選択性除草凨セトキシジム1)〔(土)2-(1-ethoxyiminobutyl) - 5 - [2 - (ethylthio) propyl] - 3- hydroxycyclohex - 2 enone, 以下 STM と略す]拉よびその代謝物の作物中で の残留実態を把握するために，分析法を検討した. STM は，作物中ですみやかに M-SO[2-(1-ethoxyiminobutyl)5-[2-(ethylsulfinyl) propyl]- 3 - hydroxycyclohex - 2 - enone]

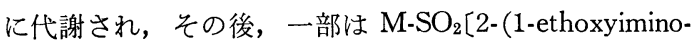
butyl) -5-[2-(ethylsulfonyl) propyl]-3-hydroxycyclohex-2enone], M2-SO [6-[2-(ethylsulfinyl) propyl]-4-oxo-2-pro-

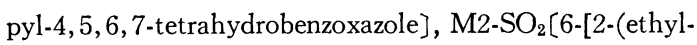
sulfonyl)propyl]-4 -oxo-2 - propyl -4, 5, 6, 7-tetrahydrobenzoxazole]に，また，作物によっては少量の 5-OH-M-SO [2-(1-ethoxyiminobutyl)-5-[2-(ethylsulfinyl) propyl]-3,5- dihydroxycyclohex-2-enone], 5-OH-M- $\mathrm{SO}_{2}$ [2-(1-ethoxyiminobutyl) -5-[2-(ethylsulfonyl) propyl] - 3, 5-dihydroxycyclohex-2-enone] にも代謝された. このほか, 光によっ て少量の M1-SO[2-(1-aminobutylidene)-5-[2-(ethylsul-

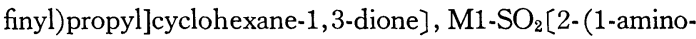
butylidene) - 5 - [2 -(ethylsulfonyl) propyl]cyclohexane-1,3dione]が生成した ${ }^{2,3)}$ (Fig. 1). STM の残留分析法を作 成し，各種作物の残留分析を実施したところ，STM は 散布後，すみやかに代謝されていることが認められたの で4)，これらの代謝物の残留分析法を作成する必要があ ると考光られた。これらの化合物を個別に分析すること は非常に時間がかかるため，残留の実態を把握すると同 時に分析を迅速に行なうことを検討した。この結果， $\mathrm{STM}, \mathrm{M}-\mathrm{SO}, \mathrm{M}-\mathrm{SO}_{2}, \mathrm{M} 2-\mathrm{SO}$ および $\mathrm{M}_{2}-\mathrm{SO}_{2}$ は $\mathrm{M} 2$ $\mathrm{SO}_{2}$ に誘導し, M1-SO, M1-SO 2 は M1- $\mathrm{SO}_{2}$ に誘導し, 
<smiles>CCCCC(CC(C)CC)N(CC)CC</smiles><smiles>CCCC(N)=C1C(=O)CC(CC(C)CC)CC1=O</smiles>

M1-S<smiles>CCCc1nc2c(o1)CC(CC(C)SCC)CC2=O</smiles>

M2-S<smiles>CC=NC(CCC)C1=C(O)CC(O)(CC(C)C(=O)OCC)CC1=O</smiles>

5-OH-M-SO<smiles>CCCc1nc2c(o1)CC(O)(CC(C)OC(C)=O)CC2=O</smiles>

$6-\mathrm{OH}-\mathrm{M} 2-\mathrm{SO}_{2}$<smiles>CCCC(=NCC)C1=C(O)CC(CC(C)C(=O)OC)CC1=O</smiles><smiles>CCCC(N)=C1C(=O)CC(CC(C)C(=O)F)CC1=O</smiles>

MI-SO<smiles>CCCc1nc2c(o1)CC(CC(C)C(F)F)CC2=O</smiles>

M2-SO<smiles>CCCC(=NCC)C1=C(O)CC(O)(CC(C)C(C)OCC)CC1=O</smiles>

$5-\mathrm{OH}-\mathrm{M}-\mathrm{SO}_{2}$<smiles>CCCc1nc2c(O)cc(CC(C)C(=O)OC(F)(F)F)cc2o1</smiles>

$\mathrm{ArM} 2-\mathrm{SO}_{2}$<smiles>CCCC(=NCC)C1=C(O)CC(CC(C)C(=O)OCC)CC1=O</smiles><smiles>CCCC=C1C(=O)CC(CC(C)C(=O)OC)CC1=O</smiles>

$\mathrm{M} 1-\mathrm{SO}_{2}$<smiles>CCCc1nc2c(o1)CC(CC(C)OCC)CC2=O</smiles>

Fig. 1 Structures and abbreviated names of authentic standard compounds.

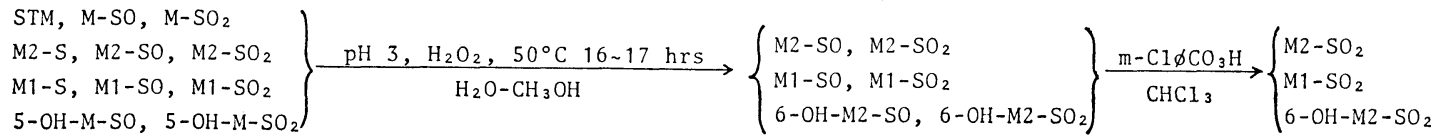

Fig. 2 Principle of the analytical method.

二つの水酸化体は $6-\mathrm{OH}-\mathrm{M} 2-\mathrm{SO}_{2}[6-[2$ - (ethylsulfonyl)propyl]-6-hydroxy - 4-oxo-2-propyl-4,5,6,7-tetrahydrobenzoxazole]に誘導することにより，9化合物を最終的に 3 化合物に変換して, 高速液体クロマトグラフ (HPLC) により定量する方法を作成することができた (Fig. 2). この方法により,実際の嘎場で収穫した 18 種類の作物に ついて残留分析を実施した。 このほか， $\mathrm{M} 1-\mathrm{SO}_{2}$ 打よび 6-OH-M2- $\mathrm{SO}_{2}$ をそれぞれ M6-SO 2 [2-butyryl-5-[(2-ethylsulfonyl) propyl] -3-hydroxycyclohex-2-enone], ArM2$\mathrm{SO}_{2}$ [6-[(2-ethylsulfonyl) propyl] - 4 -hydroxy- 2 -propylbenzoxazole]に変換後, メチル化して, 炎光光度検出器 (FPD) 付ガスクロマトグラフ (GC) により定量する方 法も作成することができた.

\section{分 析 法}

\section{1. 高速液体クロマトグラフ法}

1) 試薬打よび機器

試薬類は特級品をそのまま使用した。

標品 STM, M-SO, M-SO 2 , M1-SO, M1-SO 2 , M2-SO, $\mathrm{M} 2-\mathrm{SO}_{2}$, 5-OH-M-SO, 5-OH-M-SO, $6-\mathrm{OH}-\mathrm{M} 2-\mathrm{SO}_{2}$ は いずれも純度 98\% 以上の精製品を使用した（Fig. 1).

シリカゲル： Silica Woelm (TSC 04526)

カラムクロマト管: 内径 $1.2 \mathrm{~cm}$, 長さ $30 \mathrm{~cm}$

HPLC：島津 LC-3A（検出器 島津 SPD-II A)

2) HPLC の条件

分離管：内径 $4.6 \mathrm{~mm}$ ，長さ $25 \mathrm{~cm}$ ，ステンレス製 
充继剤: Zorbax SIL

溶離液： $2.5 \%$ メタール/ジクロロメタン

流速: $1.0 \mathrm{ml} / \mathrm{min}$

検出条件: 波長 $254 \mathrm{~nm}$, 感度 0.04 AUFS, フローセ ル容量 $8 \mu \mathrm{l}$, 室温

記録紙速度： $5 \mathrm{~mm} / \mathrm{min}$

3）検量線の作成

$\mathrm{M} 2-\mathrm{SO}_{2}, \mathrm{M} 1-\mathrm{SO}_{2}$ および 6-OH-M2-SO 2 の精製品を別 別に科り取り, クロロホルムに溶解し， $1,2,3,4$ およ び $5 \mathrm{ppm}$ の溶液を調製する. 各溶液 $20 \mu \mathrm{l}$ を HPLC に 注入し, ピーク高さを縦軸に, それぞれの化合物の重量 を横軸にとり，検量線を作成する。

4) 分析操作

均質化した試料 $25 \mathrm{~g}$ を科取し, メタノール $100 \mathrm{ml}$ を 加え磨砕抽出する. あらかじめケイソウ土を旉いた（層 高 $1 \sim 2 \mathrm{~cm}$ ) 漏斗でスラリーを吸引濾過したのち, 容器 および残椬をメタノール $50 \mathrm{ml}$ で洗い, 同様に濾過して 濾液を合わせる. 濾液に水 $150 \mathrm{ml}$ を加えたのち, 水酸 化カルシウム $10 \mathrm{~g}$ を加え, 攪拌する. これに少量のケイ ソウ土を加え吸引滤過し；容器および残渣を $50 \%$ メ夕 ノール溶液 $25 \mathrm{ml}$ で洗い，同様に濾過して濾液を合わせ る.この滤液に塩酸を添加して, $\mathrm{pH} 3.0 \pm 0.1$ に調整し, 過酸化水素水 $(30 \%) 0.5 \mathrm{ml}$ を加えたのち, $50^{\circ} \mathrm{C}$ のイン キュベーター内に一夜 (16〜17 時間) 放置する. 放置後, 溶液に塩化ナトリウム約 $5 \mathrm{~g}$ を加え, ヘキサン $100 \mathrm{ml}$ 洗浄する. 洗浄液は捨てる. その後, $100 \mathrm{ml}$ のジクロロ メタンで 3 回振とう抽出し, 水・メタノール層は捨て る. ジクロロメタン層を合わせ， $0.05 \mathrm{~N}$ 水酸化ナトリ ウム溶液（10\%塩化ナトリウム含有） $100 \mathrm{ml}$ で洗浄す る. ジクロロメタン層を別の容器に移し，アルカリ層を ジクロロメタン $100 \mathrm{ml}$ で振とう抽出する. ジクロロメ タン層を合わせ無水硫酸ナトリウムで乾燥後, 減圧濃縮 し乾固する. 乾固物を $30 \mathrm{ml}$ のクロロホルムに溶解し, $20 \mathrm{mg}$ の $m$-ク口ロ過安息香酸を加えて溶解後, $30^{\circ} \mathrm{C}$ の 水浴中で 10 分間放置する. 放置後, このクロロホルム 溶液に $2 \%$ チ才硫酸ナトリウム溶液（10\% 塩化ナトリ ウム含有） $30 \mathrm{ml}$ を加え 10 分間振とうする. この混合物 を分液漏斗に移し，クロロホルム層を別の容器に入れ， 水層をクロロホルム $20 \mathrm{ml}$ で振とう抽出する. 水層は捨 てる.クロロホルム層を合わせ, 無水硫酸ナトリウムで 乾燥し濾過後, 減压濃縮し乾固する. 乾固物を酢酸エチ ル十へキサン $(4+6, \mathrm{v} / \mathrm{v})$ の混合溶媒 $5 \mathrm{ml}$ に溶解し, あ らかじめシリカゲル $5 \mathrm{~g}$ をへキサンを用いて充填したク ロマト管中に加える.さらに同混合溶媒 $5 \mathrm{ml}$ で容器を 洗い, カラムに加える. 同混合溶媒 $140 \mathrm{ml}$ を流し捨て
る. 次にへキサン+アセトン $(7+3, \mathrm{v} / \mathrm{v}) 200 \mathrm{ml}$ で $\mathrm{M} 2$ $\mathrm{SO}_{2}, \mathrm{M} 1-\mathrm{SO}_{2}$ および 6-OH-M2-SO 2 を溶出させる. 溶出 液を濃縮乾固したのち, クロロホルムで定容し，その 20 $\mu l$ を前記条件の HPLC に注入しピーク高さを測定し， あらかじめ作成してある各化合物の検量線より $\mathrm{M} 2-\mathrm{SO}_{2}$, $\mathrm{M} 1-\mathrm{SO}_{2}$ および 6-OH-M2-SO $\mathrm{S}_{2}$ の量を求め, $\mathrm{STM}$ として の残留量を算出する. Fig. 3 に操作法の概要を示す.

\section{2. ガスクロマトグラフ法}

試薬類は HPLC 法の場合と同様であるが，このほか に $\mathrm{M} 6-\mathrm{SO}_{2}, \mathrm{ArM} 2-\mathrm{SO}_{2}$ およびジアゾメタンエチルエー テル溶液が必要である. 分析操作はカラムクロマトグラ フィーの前までは HPLC法と同様である. Fig. 4 に示 すように, カラムクロマトグラフィーで $\mathrm{M} 2-\mathrm{SO}_{2}$ のフラ クションと $\mathrm{M} 1-\mathrm{SO}_{2}$ および 6-OH-M2- $\mathrm{SO}_{2}$ のフラクショ ンに分離し， $\mathrm{M} 2-\mathrm{SO}_{2}$ のフラクションは乾固後, アセト ンに溶解し, GC に注入する. $\mathrm{M} 1-\mathrm{SO}_{2}$ と 6-OH-M2- $\mathrm{SO}_{2}$ のフラクションは, 乾固後, メタノール $15 \mathrm{ml}, 0.1 \mathrm{~N}$ 水酸化ナトリウム $15 \mathrm{ml}$ を加え 30 分間加熱還流する. この操作により M1-SO $\mathrm{SO}_{2}$ は6-SO $\mathrm{SO}_{2}$ 変換され, 6-OH$\mathrm{M} 2-\mathrm{SO}_{2}$ は $\mathrm{ArM} 2-\mathrm{SO}_{2}$ に変換される. クロロホルム抽出 後, ジアゾメタンでメチル化し, 乾固後, アセトンで定 容して GCに注入する. 検量線は $\mathrm{M} 2-\mathrm{SO}_{2}, \mathrm{M} 6-\mathrm{SO}_{2}$, $\mathrm{ArM} 2-\mathrm{SO}_{2}$ から, それぞれ分析操作に従って操作し作成 する.

\section{実験}

\section{1. 残留分析法の検討}

1) 抽出溶媒

STM を散布した各種作物を用いて, 抽出溶媒の検討 を行なった.メタノール, $50 \%$ メタノール溶液, アセト ン, $50 \%$ アセトン溶液で抽出し比較した結果, ダイズ等 の乾物を除き, 分析值に差が認められなかったので, 操 作の容易なメタノールを抽出溶媒に採用した. ダイズの 場合はメタノールのみによる抽出では不十分であり, 50 \%メタノール溶液で抽出するか, 等量の水で膨潤させた のちメタノールで抽出する必要があった. 両者について 検討した結果, 前者では濾過性が悪いため, 後者の方法 を採用した。

\section{2）オキサゾール化反応条件}

STM, M-SO, M-SO 2, 5-OH-M-SO, 5-OH-M-SO 2 は, プロパノールなどのアルコール溶液中で加熱還流する か, 希塩酸または希塩酸・メタノール混合液中で加熱す ることにより，ベックマン転位反応後脱エタノール反応 によりオキサゾール化することができた．多数の作物の 残留分析の場合，時間を有効に使うことを考え，夜間に 


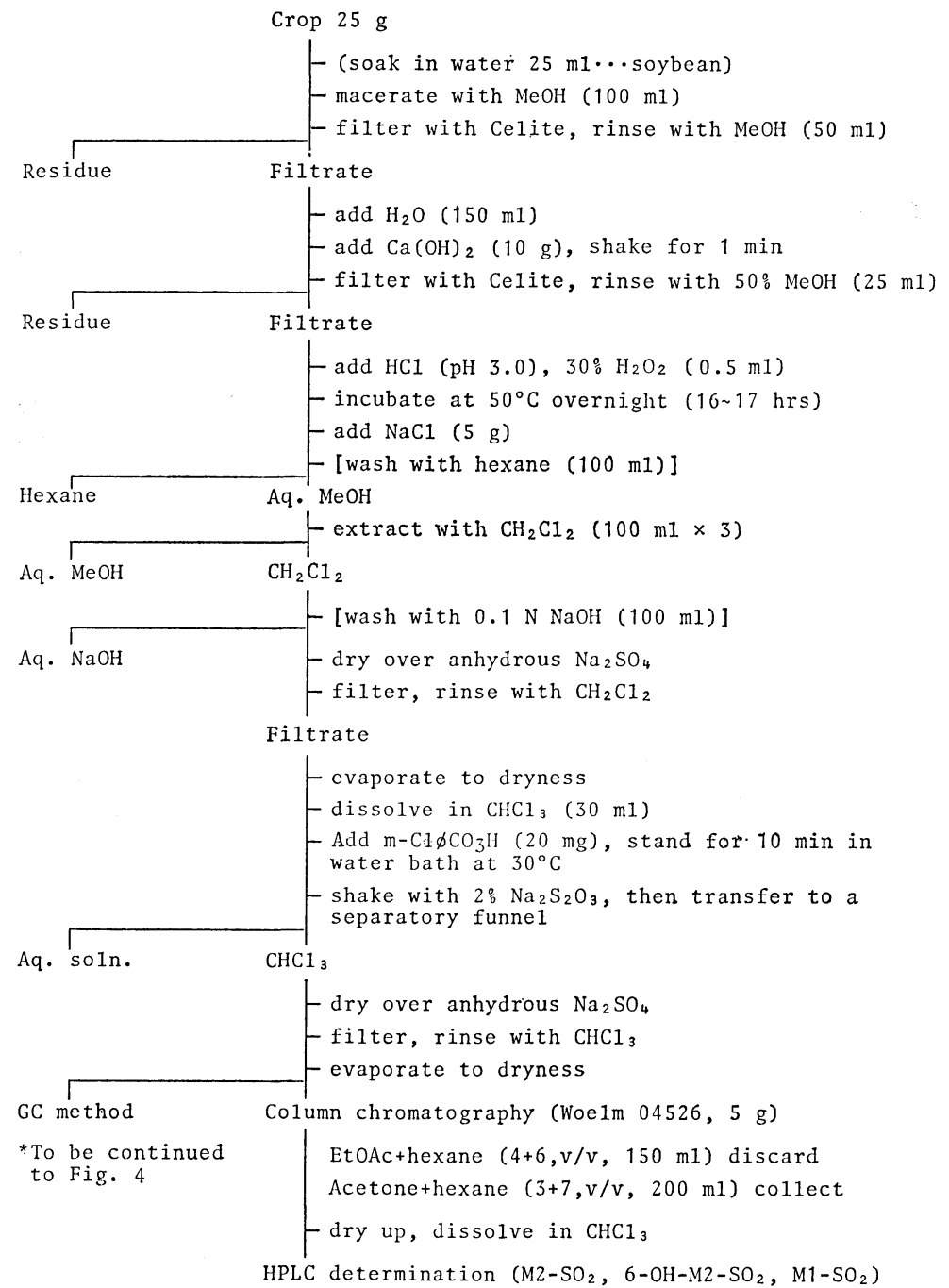

Fig. 3 Analytical flow sheet of sethoxydim and its metabolites.

Conditions of HPLC; Instrument: Shimadzu LC-3A Column: Zorbax SIL $4.6 \mathrm{~mm}$ i.d. $\times 25 \mathrm{~cm}$, Mobile phase: $2.5 \% \mathrm{MeOH} / \mathrm{CH}_{2} \mathrm{Cl}_{2} 1 \mathrm{ml} / \mathrm{min}$, Detector: UV $254 \mathrm{~nm}, 0.04$ AUFS.

オキサゾール化を行なわせることを検討した. $\mathrm{M}-\mathrm{SO}_{2}$ お よび 5-OH-M-SO 2 を $50 \%$ メタノール溶液中で $50^{\circ} \mathrm{C}$ で 17 時間反応させた場合, $\mathrm{pH} 3$ でオキサゾール化が $95 \%$ 以上進行したがこれより $\mathrm{pH}$ が大きくても小さくてもオ キサゾールの収率は低下した。 この条件下で M2-SO, $\mathrm{M} 2-\mathrm{SO}_{2}, \mathrm{M} 1-\mathrm{SO}, \mathrm{M} 1-\mathrm{SO}_{2}$ は安定であった。

3）酸化反応

STM は過酸化水素の希薄溶液中で容易にスルホキシ ドに酸化されたが，スルホンまでは酸化されなかった。 このため, オキサゾール化反応の際に少量の過酸化水素
を添加し，一旦スルホキシド化したのち，クロロホルム 中で $m$-クロロ過安息香酸によるスルホン化反応につい て検討した.この結果，スルホキシド化は酸性で行なう 必要があり，アルカリ性では回収率は極端に低下した。 また, $50 \%$ メタノール溶液 $300 \mathrm{ml}$ 中, $\mathrm{pH} 3.0$ で反応す る場合, 過酸化水素を $0.5 \mathrm{ml}$ 用いた場合の反応率が最 もよく $95 \%$ であった. 過酸化水素濃度が高すぎても反 応率は低下した. $30 \mathrm{ml}$ のクロロホルム中で $20 \mathrm{mg}$ の クロロ過安息香酸による $\mathrm{M} 2-\mathrm{SO}$ から $\mathrm{M} 2-\mathrm{SO}_{2}$ への酸化 反応は室温でも定量的に進行したが，M1-SO から M1- 


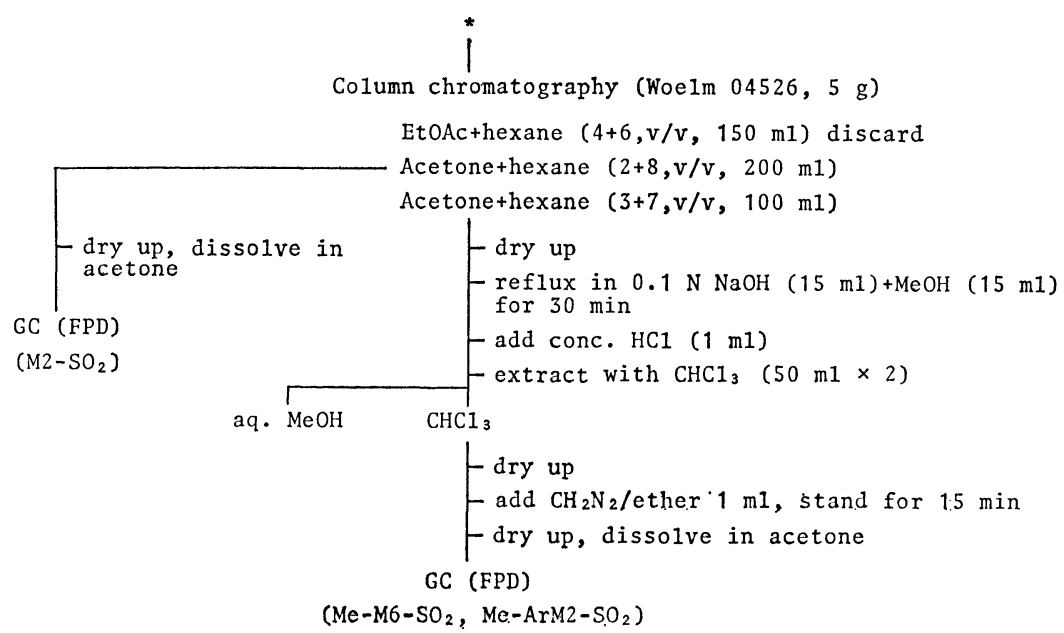

Fig. 4 Analytical flow sheet of sethoxydim and its metabolites by GC (*Continued from Fig. 3).

Conditions of GC (FPD); Instrument: Shimadzu GC-7A, Column: 5\% OV-210 on Uniport HP 80-100 mesh packed in $3 \mathrm{~mm}$ i.d. $\times 50 \mathrm{~cm}$ length glass column, Column temperature: $270^{\circ} \mathrm{C}$ $\left(\mathrm{M} 2-\mathrm{SO}_{2}\right), 250^{\circ} \mathrm{C}\left(\mathrm{Me}-\mathrm{M} 6-\mathrm{SO}_{2}, \mathrm{Me}-\mathrm{ArM} 2-\mathrm{SO}_{2}\right)$, Injection temperature: $280^{\circ} \mathrm{C}\left(\mathrm{M} 2-\mathrm{SO}_{2}\right), 270^{\circ} \mathrm{C}$ (Me-M6-SO, $\mathrm{Me}-\mathrm{ArM} 2-\mathrm{SO}_{2}$ ), Carrier gas: $\mathrm{N}_{2} 70 \mathrm{ml} / \mathrm{min}\left(\mathrm{M} 2-\mathrm{SO}_{2}\right), 45 \mathrm{ml} / \mathrm{min}$ (Me-M6-SO Me-ArM2- $\mathrm{SO}_{2}$ ), Air: $0.6 \mathrm{~kg} / \mathrm{cm}^{2}, \mathrm{H}_{2}$ : upper $0.3 \mathrm{~kg} / \mathrm{cm}^{2}$, lower $0.6 \mathrm{~kg} / \mathrm{cm}^{2}$, Attenuation: 32 , Range 10.

$\mathrm{SO}_{2}$ への酸化は $30^{\circ} \mathrm{C}$ の水浴中で 10 分間の加温条件が 最適であった．この場合，反応後，ただちにチオ硫酸ナ トリウム溶液と激しく振とうすることにより，反応停止 を行なう必要があった。また，反応温度が低い場合は， 酸化不十分で反応率は低下した. Table 1 に $m$-ク口ロ過 安息香酸による反応率の温度による影響を示した。

4）クリンフップ条件

(1) 液液分配

STM は酸性 $50 \%$ メタノール溶液からへキサンに転 溶されたが，オキサゾール体および酸化体は転溶されな かったので，オキサゾール化・酸化反応後へキサン洗浄 することができた。この操作はとくに油状物質の多い作 物（ダイズ, ナタネ, アズキ, ラッカセイ, ミカン果皮 など）や，葉緑素の多い作物（ホウレンソウ，テンサイ 葉など）の場合有効であったが，作物（ニンジン, バレ イショ,テンサイ根, ダイコンなど）によっては, この 操作は必要なかった. $50 \%$ メタノール溶液からジクロロ メタンに転溶する場合，水酸化体は 3 回の液液分配が必 要であった. ニンジン, バレイショ, テンサイ根, ダイ コンなどでは，アルカリ洗浄は行なわなくても分析でき た.
Table 1 Effect of temperature on oxidation of M1-SO and M2-SO with $m$-chloroperbenzoic acid.

\begin{tabular}{ccc}
\hline \multirow{2}{*}{$\begin{array}{c}\text { Temp. } \\
\left({ }^{\circ} \mathrm{C}\right)\end{array}$} & \multicolumn{2}{c}{ Yield (\%) } \\
\cline { 2 - 3 } & ${\mathrm{M} 1-\mathrm{SO}_{2}}$ & ${\mathrm{M} 2-\mathrm{SO}_{2}}$ \\
\hline 20 & $64-90$ & 100 \\
30 & $89-95$ & 100 \\
40 & $40-56$ & 100 \\
\hline
\end{tabular}

\section{（2）水酸化カルシウム沈殿処理}

水酸化カルシウム沈殿によるクリンフップを採用し た.この処理により, 水酸化ナトリウム溶液での洗浄時, 打よび酸化後のチ才硫酸ナトリウムとの振とう時に乳濁 がなく，操作しやすくなったほか，オキサゾール化反応 後の沈殿物を濾過する必要がなくなった，M1-SO, M1$\mathrm{SO}_{2}$ はアルカリ性下で長く放置しておくと分解するの で, この操作は短時間（10 分以内）で行ない，ただちに 塩酸を加光， $\mathrm{pH} 3$ に調整する必要があった。 ただし， ナタネの分析は, この水酸化カルシウム沈殿処理を行な わないほうが妨害成分が少なく，クロマトグラムがきれ いであった。 
(3) カラムクロマトグラフィー

シリカゲルを用いてカラムクロマトグラフィーの検討 を行なった.シリカゲルは Woelm TSC-04526, 和光純 薬 C-200を用い，展開溶媒としてアセトンーヘキサン系 および酢酸エチルーへキサン系を用いて検討した結果， 分析法に示した条件で各種作物の妨害成分の大部分が除 去され, 各誘導体は定量的に回収された. Fig. 4 に示し た $\mathrm{M} 2-\mathrm{SO}_{2}$ のフラクションと $\mathrm{M} 1-\mathrm{SO}_{2}$ と $6-\mathrm{OH}-\mathrm{M} 2-\mathrm{SO}_{2}$ のフラクションに分離したのち,それぞれ HPLC 定量す る方法も，妨害成分が多いナタネなどでは有効である.

(4) 特殊な作物のクリンアップ

大多数の作物の場合，前記のクリンアップで十分であ るが, ミカン果皮, ナタネのような妨害成分の多い特殊 な作物の場合は, 前記のカラムクロマトグラフィーの後 次のような Sep-pak@ $\mathrm{C}_{18}$ (Waters 社製) を用いるクリン アップを行なう。すなわち，Sep-pak® $\mathrm{C}_{18}$ をアセトニ トリル $10 \mathrm{ml}$, 次に蒸留水 $10 \mathrm{ml}$ であらかじめ洗浄した のち, カラムクロマトグラフィー後の濃縮乾固物の入っ た容器を蒸留水 $10 \mathrm{ml}$ で洗浄して, この Sep-pak@ $\mathrm{C}_{18}$ に加え流下する. このフラクションは捨てる. 次に水十 アセトニトリル $(9+1, \mathrm{v} / \mathrm{v}) 10 \mathrm{ml}$ で容器を洗い, Seppak@ に加え流下する. このフラクションは捨てる. 次 に水十アセトニトリル $(8+2, \mathrm{v} / \mathrm{v}) 20 \mathrm{ml}$ で容器を洗い, Sep-pak® に加え流下する．このフラクションに各誘導 体が溶出される。これを減圧乾固後, クロロホルムに容 解し，高速液体クロマトグラフに注入する.

5） HPLCによる定量

$\mathrm{M} 2-\mathrm{SO}_{2}$ および 6-OH-M2- $\mathrm{SO}_{2}$ はいずれも二つの不斉 炭素を有するため, 異性体の混合物である，異性体を個 別に定量する必要のない場合は，異性体が分離しないよ うな条件で定量するほうが分析が簡単になる。逆相系の Zorbax ODS, Zorbax CN, $\mu$ Bondapak $\mathrm{C}_{18}$, Spherisorb $\mathrm{S} 5 \mathrm{P}$ では $\mathrm{M} 2-\mathrm{SO}_{2}$ の異性体が分離し，ッインピークとな った. 順相系の Zorbax SIL, $\mu$ Porasil, Micropak SI-10 のような吸着型カラムで, 流速 $1 \mathrm{ml} / \mathrm{min}$, 溶出時間 12 分以内の測定条件下では両化合物ともシングルピークで あった. Zorbax $\mathrm{NH}_{2}$ を順相系で使用した場合は, M2$\mathrm{SO}_{2}$ は分離しないが，6-OH-M2- $\mathrm{SO}_{2}$ がッインピークに 分離した。

以上の検討により，作物からの妨害成分との分離がよ く，また，異性体が分離しないZorbax SILを採用した。 $\mathrm{M} 2-\mathrm{SO}_{2}$ および 6-OH-M2-SO $\mathrm{S}_{2}$ は, $247 \mathrm{~nm}$ に極大吸収 を示し(それぞれ $\left.\varepsilon: 0.88 \times 10^{4}, 0.82 \times 10^{4}\right), \mathrm{M} 1-\mathrm{SO}_{2}$ は $290 \mathrm{~nm}\left(\varepsilon: 1.58 \times 10^{4}\right)$ および $246 \mathrm{~nm}\left(\varepsilon: 1.64 \times 10^{4}\right)$ に 極大吸収を示した．実際に高速液体クロマトグラフにこ
れらの化合物を注入し，247 nm と $254 \mathrm{~nm}$ で比較したと ころ，感度にほとんど差がみられなかったので，波長可 変検出器, 固定波長検出器のいずれでも測定可能な 254 $\mathrm{nm}$ を測定波長とした。作物成分が分析を妨害する場合 は, 溶離液中のメタノール濃度を変動させると多くの場 合, 作物成分と誘導体が分離した。 また，溶離液をエ夕 ノール/ジクロロメタン系とするとよい場合（ナタネ）も あった。

6) GC による定量

$\mathrm{M} 2-\mathrm{SO}_{2}$ は $\mathrm{GC}$ での定量が可能であったが，6-OHM2-SO, M1-SO 2 は OV-17, DC-11, PEG-HT, OV-1, DC-200，OV-210 を用いて検討したが，ピークが現われ なかった，力ラムに対する吸着性を弱めるために，6$\mathrm{OH}-\mathrm{M} 2-\mathrm{SO}_{2}$ の $\mathrm{OH}$ 基のアセチル化, メチル化について 検討したが，これらの反応はほとんど進行しなかった。 6-OH-M2- $\mathrm{SO}_{2}$ はクロロホルム中で五酸化りンと反応す るか, またはアルカリ溶液中で加熱することにより脱水 して芳香族化し， $\mathrm{ArM} 2-\mathrm{SO}_{2}$ に変化した. 五酸化リンと の反応では反応時間を長くしても反応率は $85 \%$ 程度で 一定であり，それ以上は進まなかった．分析法に示した アルカリ加水分解条件下では加熱還流 30 分間で反応は 定量的に進行した. ArM2- $\mathrm{SO}_{2}$ はフェノール性 $\mathrm{OH}$ 基を 有するため, GC に注入してもピークが現われなかった. この $\mathrm{OH}$ 基のトリメチルシリルイミダゾールを用いるシ リル化，ジアゾメタンによるメチル化を検討した。 シリ ル化剂と混合しただけでは反応は進行しなかったが， GC 中で反応することが認められた．しかし，この試薬 は反応溶媒のアセトン中の水分で分解されやすく回収率 が一定しなかった：ジアゾメタンでは，室温で 15 分間 放置することにより定量的にメチル化され，Me-Ar-M2$\mathrm{SO}_{2}$ に誘導された. $\mathrm{M} 1-\mathrm{SO}_{2}$ は 6-OH-M2-SO 2 とまった く同様に操作することにより， M6-SO 2 を経て Me-M6$\mathrm{SO}_{2}$ に変化し, $\mathrm{GC}$ で定量可能であることが認められた.

7）検出限界括よび回収率

(1) HPLC 法

各誘導体をとれぞれ $5 \mathrm{ng}$ 注入した時, ピーク高さ 4〜 $5 \mathrm{~mm}$ の明瞭なピークが認められたので，これを最小検 出量とした。試料科取量を $25 \mathrm{~g}$, 最終液量を $2 \mathrm{ml}$, 注入 量を $20 \mu \mathrm{l}$ とした場合，検出限界は $0.02 \mathrm{ppm}$ となる.

(2) GC 法

各誘導体の最小検出量は $5 \mathrm{ng}$ であった. 試料量を 25 $\mathrm{g}$, 最終液量を $1 \mathrm{ml}$, 注入量を $10 \mu \mathrm{l}$ とした場合, 検出 限界は $0.02 \mathrm{ppm}$ となる。

作物に STM およびその代謝物を添加して分析し，回 収率を求めた結果を Table 2 に示す，いずれの場合も 
Table 2 Fortified recovery of sethoxydim and its metabolites.

\begin{tabular}{|c|c|c|c|c|}
\hline \multirow{2}{*}{ Crop } & \multicolumn{2}{|c|}{ Compound added } & \multicolumn{2}{|c|}{ Recovery (\%) } \\
\hline & Name & Conc. (ppm) & Found & Average \\
\hline \multirow{12}{*}{ Soybean seed } & STM & 0.2 & $88.2,88.0$ & 88.1 \\
\hline & STM & 0.05 & $72.4,70.0$ & 71.2 \\
\hline & M-SO & 0.2 & $88.0,88.0$ & 88.0 \\
\hline & $\mathrm{M}-\mathrm{SO}_{2}$ & 0.2 & $94.3,93.7$ & 94.0 \\
\hline & M2-SO & 0.2 & $92.4,87.8$ & 90.1 \\
\hline & $\mathrm{M} 2-\mathrm{SO}_{2}$ & 0.2 & $95.3,96.4$ & 95.9 \\
\hline & M1-SO & 0.2 & $75.5,70.5$ & 73.0 \\
\hline & M1-SO & 0.05 & $80.2,77.1$ & 78.7 \\
\hline & $\mathrm{M} 1-\mathrm{SO}_{2}$ & 0.2 & $88.0,86.9$ & 87.5 \\
\hline & 5-OH-M-SO & 0.2 & $80.3,78.2$ & 79.3 \\
\hline & 5-OH-M-SO & 0.05 & $80.4,77.8$ & 79.1 \\
\hline & 5-OH-M-SO & 0.2 & $80.1,75.0$ & 77.6 \\
\hline \multirow{3}{*}{ Green soybean } & STM & 0.2 & $82.3,79.6$ & 81.0 \\
\hline & M1-SO & 0.2 & $75.0,71.5$ & 73.3 \\
\hline & 5-OH-M-SO & 1.0 & $89.2,85.4$ & 87.3 \\
\hline \multirow{3}{*}{ Sugar beet root } & STM & 0.2 & $83.4,80.7$ & 82.1 \\
\hline & M1-SO & 0.2 & $77.1,75.7$ & 76.4 \\
\hline & 5-OH-M-SO & 0.2 & $82.5,80.5$ & 81.5 \\
\hline \multirow{3}{*}{ Sugar beet leaf } & STM & 0.2 & $83.2,80.9$ & 82.1 \\
\hline & M1-SO & 0.2 & $77.0,75.5$ & 76.3 \\
\hline & 5-OH-M-SO & 0.2 & $85.8,80.3$ & 83.1 \\
\hline \multirow{3}{*}{ Carrot } & STM & 0.2 & $77.5,76.8$ & 77.2 \\
\hline & M1-SO & 0.2 & $88.0,86.5$ & 87.3 \\
\hline & 5-OH-M-SO & 0.2 & $74.3,74.3$ & 74.3 \\
\hline \multirow{3}{*}{ Potato } & STM & 0.2 & $84.0,80.0$ & 82.0 \\
\hline & $\mathrm{M} 1-\mathrm{SO}$ & 0.2 & $80.7,80.0$ & 80.4 \\
\hline & 5-OH-M-SO & 0.2 & $92.3,90.2$ & 91.3 \\
\hline \multirow{3}{*}{ Cabbage } & STM & 0.2 & $76.2,74.8$ & 75.5 \\
\hline & M1-SO & 0.2 & $74.4,72.6$ & 73.5 \\
\hline & 5-OH-M-SO & 0.2 & $79.0,75.6$ & 77.3 \\
\hline \multirow{3}{*}{ Strawberry } & STM & 0.2 & $89.2,86.9$ & 88.1 \\
\hline & M1-SO & 0.2 & $76.7,76.0$ & 76.4 \\
\hline & 5-OH-M-SO & 0.2 & $93.8,91.7$ & 92.8 \\
\hline
\end{tabular}

70\% 以上の回収率が得られた。また，ダイズに STM， M1-SO, 5-OH-M-SO 係数はそれぞれ $2.1,4.1,5.2 \%($ 各 $n=5)$ であった。 クロマトグラム例を Fig. 5 に示す.

\section{2. 残留分析}

各地の農業試験場および当社の國場でナブ乳剤 (STM $20 \%$ 含有）を散布した，ダイズ，エダマメ，テンサイ， ニンジン, バレイショ, ミカン, キャベッ, イチゴ, ト マト, タマネギ, ダイコン, スイカ, ハクサイ, ホウレ
ソソウ, サヤインゲン，カンショ，アズキ，ナタネを分 析し，STM および関連化合物の残留量を調べた。残留 分析の結果の一部を Table 3 に示す.これらの結果によ り，主たる残留物は $\mathrm{M} 2-\mathrm{SO}_{2}$ に誘導される化合物であ り， $\mathrm{M} 1-\mathrm{SO}_{2}$ に誘導される化合物は，ほとえど無視でき る程度であった. 6-OH-M2- $\mathrm{SO}_{2}$ に誘導される化合物は ダイズで比較的多く，このほか，バレイショ，イチゴな どにも，わずかながら残留が認められた。 
Table 3 Crop application history and the residual amount of STM and its metabolites.

\begin{tabular}{|c|c|c|c|c|c|c|}
\hline \multirow{2}{*}{ Crop } & \multirow{2}{*}{ Location } & \multirow{2}{*}{$\begin{array}{c}\text { Dosage } \\
(\mathrm{kg} \text { ai/ha) }\end{array}$} & \multirow{2}{*}{$\begin{array}{l}\mathrm{PHI}^{\mathrm{a}} \text { ) } \\
\text { (days) }\end{array}$} & \multicolumn{3}{|c|}{ Residue (ppm as STM) ${ }^{b}$ ) } \\
\hline & & & & $\mathrm{M} 2-\mathrm{SO}_{2}$ & $\mathrm{M} 1-\mathrm{SO}_{2}$ & $6-\mathrm{OH}-\mathrm{M} 2-\mathrm{SO}_{2}$ \\
\hline \multirow{6}{*}{ Soybean seed } & Nagano & 0.5 & 49 & 1.32 & 0.04 & 0.68 \\
\hline & & 0.5 & 63 & 0.44 & $<0.02$ & 0.46 \\
\hline & & 0.5 & 51 & 1.17 & 0.04 & 1.17 \\
\hline & Shizuoka & 0.5 & 58 & 0.44 & $<0.02$ & 0.43 \\
\hline & & 0.5 & 72 & 0.02 & $<0.02$ & $<0.02$ \\
\hline & & 0.5 & 80 & $<0.02$ & $<0.02$ & $<0.02$ \\
\hline \multirow[t]{2}{*}{ Sugar beet root } & Hokkaido & 0.5 & 95 & $<0.02$ & $<0.02$ & $<0.02$ \\
\hline & Hokkaido & 0.5 & 102 & $<0.02$ & $<0.02$ & $<0.02$ \\
\hline \multirow[t]{2}{*}{ Sugar beet leaf } & Hokkaido & 0.5 & 95 & $<0.02$ & $<0.02$ & $<0.02$ \\
\hline & Hokkaido & 0.5 & 102 & $<0.02$ & $<0.02$ & $<0.02$ \\
\hline \multirow{3}{*}{ Carrot } & & & 7 & 0.24 & $<0.02$ & $<0.02$ \\
\hline & Yamanashi & 0.5 & 21 & 0.18 & $<0.02$ & 0.02 \\
\hline & & & 35 & 0.07 & $<0.02$ & $<0.02$ \\
\hline \multirow[t]{2}{*}{ Potato } & Yamanashi & 0.5 & 31 & 0.12 & $<0.02$ & 0.11 \\
\hline & & & 92 & 0.04 & $<0.02$ & 0.04 \\
\hline \multirow{3}{*}{ Cabbage } & & & 7 & 0.17 & $<0.02$ & $<0.02$ \\
\hline & Kanagawa & 0.5 & 21 & 0.30 & $<0.02$ & $<0.02$ \\
\hline & & & 35 & 0.12 & $<0.02$ & 0.03 \\
\hline \multirow[t]{2}{*}{ Strawberry } & Hyogo & 0.5 & 30 & 0.13 & $<0.02$ & 0.22 \\
\hline & Kanagawa & 0.5 & 31 & $<0.02$ & $<0.02$ & 0.02 \\
\hline
\end{tabular}

a) Preharvest interval.

b) Average of duplicate analyses.

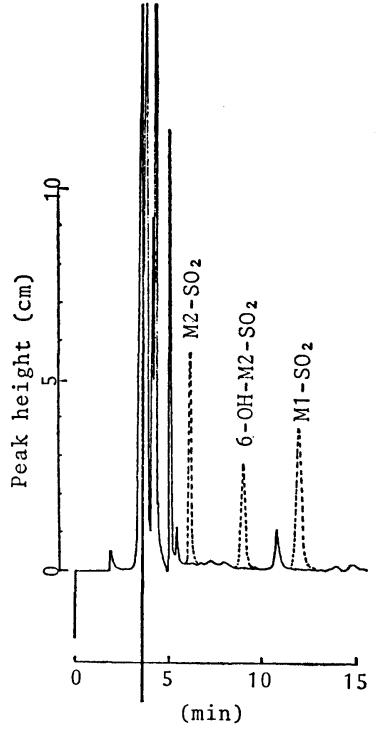

(A)

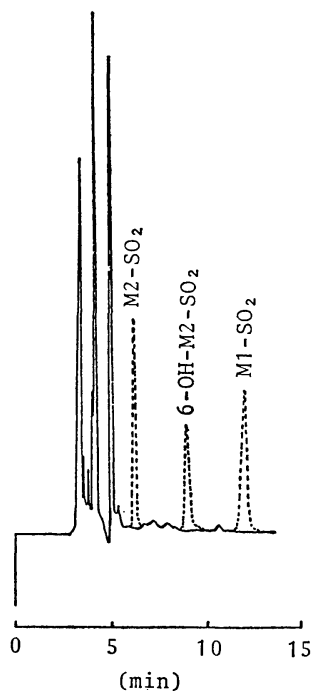

(B)

\begin{abstract}
考
察

STM, M-SO, M-SO 2 などは，エノール構造を有する ため順相系 HPLC ではテーリングしやすかった．逆相 系 HPLC ではオキシム位の $E, Z$ 異性体が生成し, 水系 溶媒やアルコール中ではその比が変動しやすかった。ま た，M-SO や M2-SO は側鎖メチル基のついた炭素の不 斉，スルホキシドのイオウの不斉による異性体のため， HPLC でそのまま分析するとッインピークとなった. このように多数の代謝物があり，また，それぞれが異性 体を有するため，これらをそのまま定量するのは非常に 困難であった。そこで，これらの残留成分をできるだけ
\end{abstract}

Fig. 5 Examples of liquid chromatogram.

Solid line: Unfortified sample, Dotted line: Standard chemicals (50 ng). (A) Soybean seed, (B) Sugar beet root, Amount of sample: $25 \mathrm{~g}$, Final volume: $2 \mathrm{ml}$, Injection volume: $20 \mu \mathrm{l}$. 
少数の化合物に誘導し，定量することを考えた．これら の対象化合物を酸性下で加熱し, さらに酸化するととに より, $\mathrm{M} 2-\mathrm{SO}_{2},{\mathrm{M} 1-\mathrm{SO}_{2}}_{2}$ おび 6-OH-M2-SO 2 亿誘導さ れることが認められ，これらは順相系の HPLC ではそ れぞれシャープな単一ピークとして現われ, 残留分析法 を確立することができた．しかし， M2-SO $2,6-\mathrm{OH}-\mathrm{M} 2-$ $\mathrm{SO}_{2}$ ともにそれぞれ，二つの不斉炭素を有するため異性 体の混合物であり，これらが分離しない条件を用いるこ とが必要であった。さらに誘導化を行なえば，GC によ る残留分析も可能であった. 検出器は選択性の点で炎光 光度検出器が優れていたが, 電子捕獲検出器, 熱イオン 検出器, 質量選択検出器でも妨害成分が少ない場合は分 析可能と考元られた. HPLC 法のほうが GC 法より操 作が短く簡単であった．土塨の残留分析も本法と同様な 原理で分析できるが，その場合，土塨では水酸化物は生 成しないので 6-OH-M2- $\mathrm{SO}_{2}$ の定量は不要であった.

STM 単独の残留分析法も確立されているが，STMはき わめて短時間に消失し, 代謝物に変換されてしまうの で4)，残留実態を考慮すると，作物，土塨とも本分析法 で分析するのが好ましいと考元られた．本分析法で作物 残留実態を調べたところ， $\mathrm{M}^{-}-\mathrm{SO}_{2}$ に誘導される化合物 はまったく検出されないか, 検出されたとしても，その 残留量は，ほとえど無視できる程度であり，通常の残留 分析の場合には $\mathrm{M}^{-}-\mathrm{SO}_{2}$ の分析の必要性はないものと 判断された。 また，本分析法を応用し，各代謝物を液液 分配による分離, オキサゾール化反応の有無, 酸化の有 無により分離定量した結果, $\mathrm{M} 2-\mathrm{SO}_{2}$ に誘導される代謝 物の大部分は $\mathrm{M}-\mathrm{SO}$ と $\mathrm{M}-\mathrm{SO}_{2}$ であり，6-OH-M2- $\mathrm{SO}_{2}$ に
誘導される代謝物は 5-OH-M-SO 2 と 5-OH-SO の比が 8 対 2 程度であり，6-OH-M2- $\mathrm{SO}_{2}$ は検出されなかった。

\section{要 約}

作物中に残留しているセトキシジム (STM) およびそ の代謝物の分析法を検討した. STM は数多くの代謝物 に分解するため, これらの代謝物を $\mathrm{M} 2-\mathrm{SO}_{2}, \mathrm{M}^{2}-\mathrm{SO}_{2}$ 打 よび 6-OH-M2- $\mathrm{SO}_{2}$ の三つの化合物に誘導化して HPLC (紫外線検出器) で定量する方法を作成した. GC 法 (FPD) についても検討したが, HPLC 法が優れていた. この方法を用いて, 围場で収穫した 18 種類の作物につ いて残留分析を行なった結果, 残留物の多くは $\mathrm{M} 2-\mathrm{SO}_{2}$ に誘導される化合物であり, これらは $\mathrm{M}-\mathrm{SO}, \mathrm{M}-\mathrm{SO}_{2}$ と 推定された. ダイズ等, 数種類の作物中に 6-OH-M2$\mathrm{SO}_{2}$ に誘導化される水酸化体（主として $5-\mathrm{OH}-\mathrm{M}-\mathrm{SO}_{2}$ ) の存在が認められたが，いずれの作物中でも $\mathrm{M} 1-\mathrm{SO}_{2}$ に 誘導される代謝物は，まったく検出されなかったか，検 出されてもきわめてわずかな量で分析の必要性は認めら れなかった。

\section{引用 文 献}

1）石川尚雄・岩滝 功・佐脇幹夫：農薬誌 $\mathbf{1 0}, 301$ (1985)

2) K. Ishihara, T. Gomyo, Y. Soeda \& S. Ono: Abstr. 5th Int. Congr. Pestic. Sci., Vd-6, 1982.

3) 五明 健- 岩滝 功 - 添田吉則 - 小野成男: 日本 農薬学会第 12 回大会講演要旨集, p. 140, 1987

4) 五明 健・小野成男：農薬誌 12,741（1987） 